\title{
FATIGUE TESTING STRUCTURAL STEEL AS A FACTOR OF SAFETY OF TECHNICAL FACILITIES MAINTENANCE
}

\author{
Robert Ulewicz ${ }^{1}$, Magdalena Mazur ${ }^{1 *}$ \\ ${ }^{1}$ Institute of Production Engineering, Faculty of Management, Częstochowa University of Technology, \\ Al. Armii Krajowej 19B, 42-201 Czestochowa, Poland \\ * corresponding author: Tel.: +48 343250 399, e-mail: mazur.m@zim.pcz.pl
}

\begin{abstract}
Resume
Guarantee of quality and safety exploitation of machines and equipment is a significant factor in the design and manufacture of these components. This paper presents an analysis of fatigue test results of samples in the bending load on the rotation in the range from $10^{4}$ to $10^{7}$, the number of cycles of applied load, with a frequency of $40 \mathrm{~Hz}$. Whöler curve shows the results of the fatigue properties of steel S355J2 which is used in the construction of vehicles. There was also carried out a fractographic analysis.
\end{abstract}

\author{
Article info \\ Article history: \\ Received 20 September 2013 \\ Accepted 20 November 2013 \\ Keywords: \\ fatigue tests, \\ construction steel, \\ fatigue crack, \\ fractography

\section{Introduction}

The Concept of fatigue can be defined as a process of structural changes of the material and its features, which is induced by vibration or cyclic weight bearing. Material fatigue is a process of continuous accumulation of damage formed in a sufficiently long time. This process is caused by variables of mechanical stress which cause the nucleation and spreading (propagation) of cracks, revealed in the end as destruction of the material (WYRZYKOWSKI J.W., et al. 1999).

The information about the fatigue strength of the material becomes essential for solving the general problem of improving the reliability and durability of modern machines and constructions. The dynamic development of technology makes it necessary to carry out research aimed at increasing the length of exploitation cycle and reliability of modern technical objects (VĚCHET, et al. 2001). The analysis of causes for damage to machine components and constructions shows that most of over $80 \%$ of all cases are due to the fatigue cracking. Manufacturers are interested in optimizing operational costs and the increase of production. Therefore, manufacturers pay attention to getting the greatest durability of produced objects. This is obtained by looking for new construction solutions of their products and by the application of appropriate materials (materials with appropriate properties).

\section{Results of the fatigue tests}

The main characteristics of fatigue are obtained after the formation of the fatigue curve, which is a graphical representation of the relationship between the level of stress $\sigma$ (or strain $\varepsilon$ ) and the fatigue life $\mathrm{N}$ in tests performed in the same conditions (number of cycles, type of samples).

Fatigue characteristics (dependence $\sigma=f$ $(N)$ ) of steel have been determined at low testing frequency. Schematic presentation of the test device along with the course of bending moment and loading distribution on the section is provided in Figure 1 (MIKOVÁ K., et al., 2012, BOKU゚VKA O., et.al., 2002). Stress ratio of the loading cycle in such tests is always $\mathrm{R}=-1$.

To determine the fatigue strength of the material 12 specimens of S355J2 steel underwent a low cycle fatigue test. The results obtained in this way were the basis to build the SN curve. 


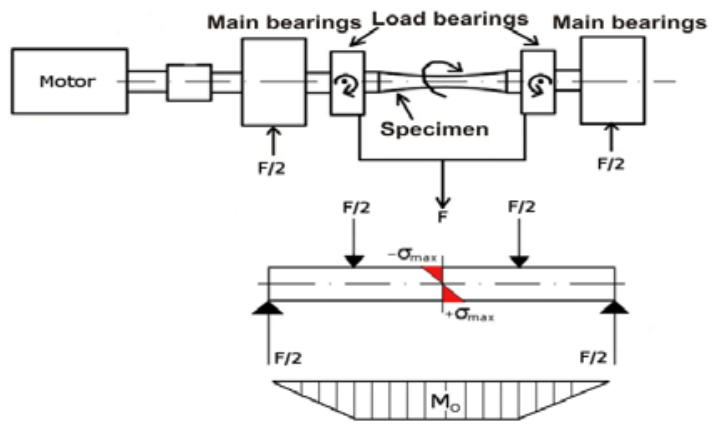

Fig. 1. Rotoflex - equipment testing bending strength in the rotation mode

The fatigue tests were performed with the use of the Rotoflex machine realizing load in bending in the rotation mode. During the load cycle the stress ratio was $\mathrm{R}=-1$, with loading frequency $40 \mathrm{~Hz}$ and temperature $20^{\circ} \mathrm{C} \pm 3^{\circ} \mathrm{C}$. During the test the working part of the specimens was cooled by means of fans (ULEWICZ R. et.al. 2012).

The test results formed a dependency curve between the amplitude of applied load and the number of cycles to the specimen crack $\sigma_{a}=$ $f\left(N_{f}\right)$ (Figure 2). The tested material shows a distinct fatigue limit of $\sigma_{C}=290 \mathrm{MPa}$ for the loading cycles $10^{6}$ $<N<10^{7}$.

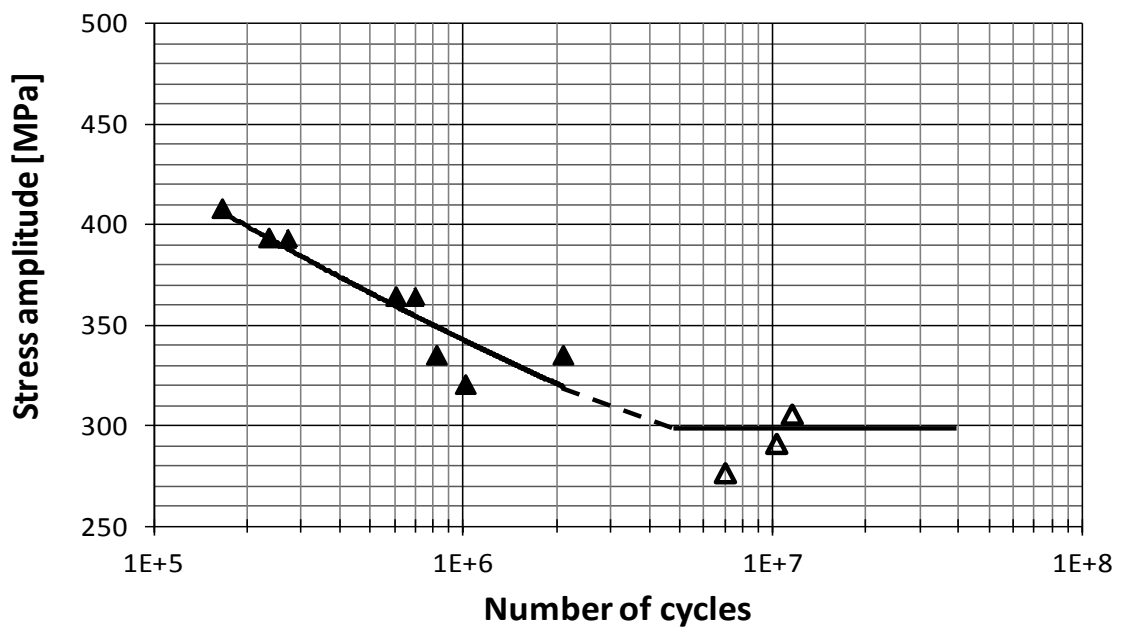

Fig. 2. Diagram of dependency between the load amplitude and the number of cycles of the tested steel

In order to learn about the nature of the fatigue process of the tested materials

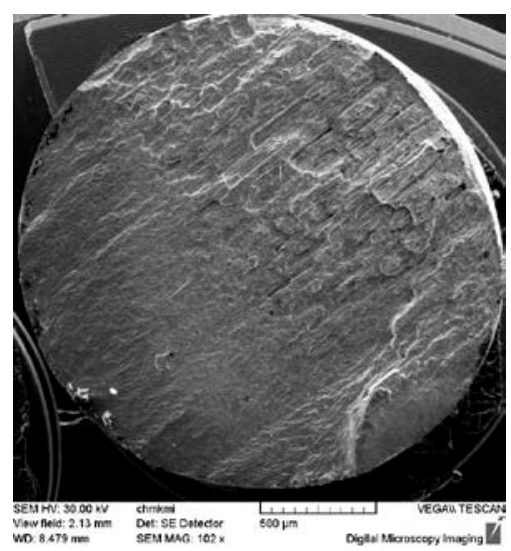

Fig. 3. Overview of the fracture surface

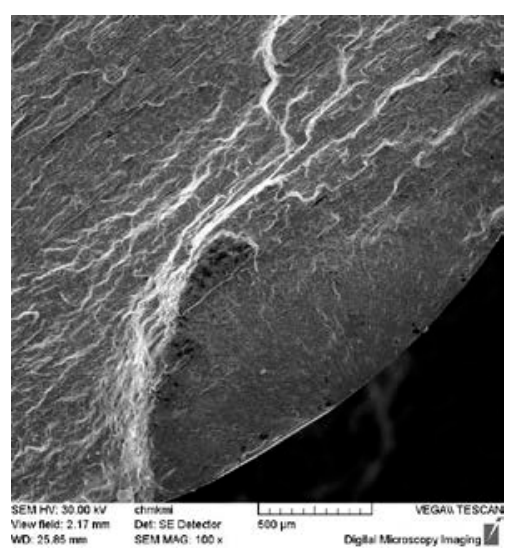

Fig. 4. The initiation place of fatigue fracture

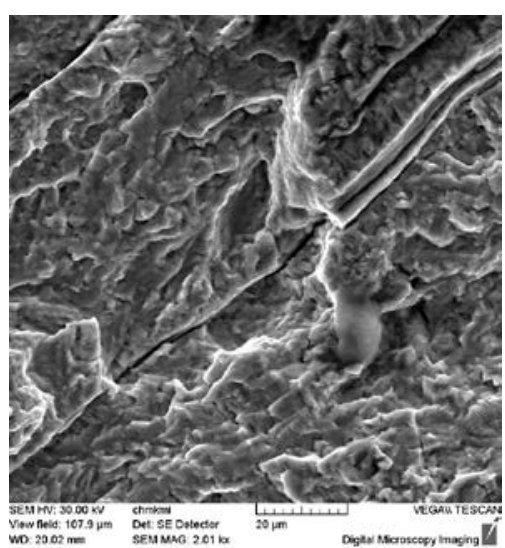

Fig. 5. Secondary cracks 


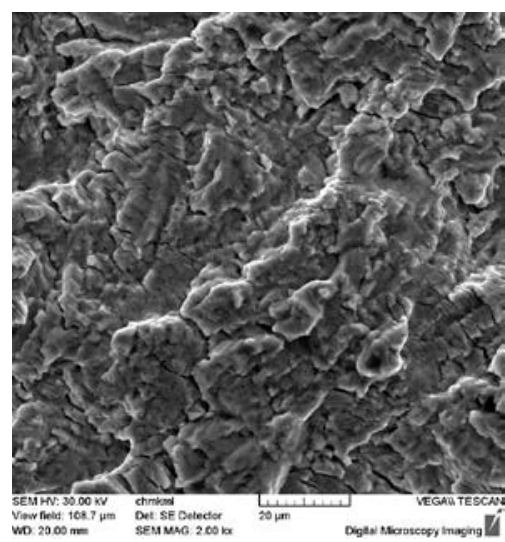

Fig. 6. Striations on the fatigue fracture surface

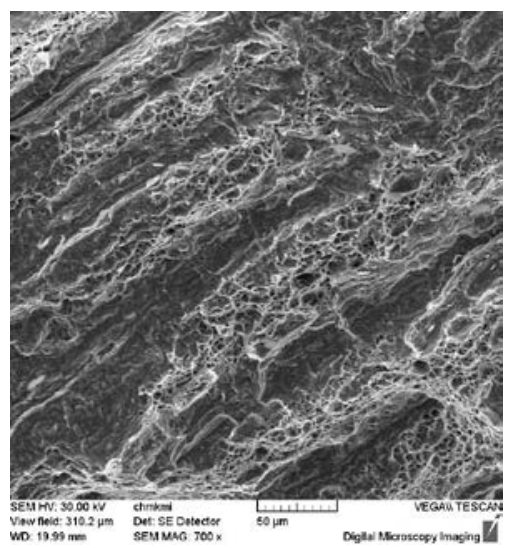

Fig. 7. Final overload fracture surface

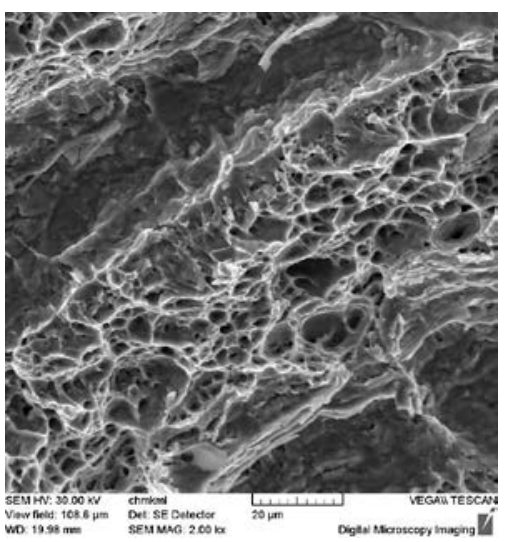

Fig. 8. Transcrystalline ductile fracture of ferrite with dimple morphology
The area has a nature of transcrystalline fatigue fracture with clear secondary cracks, arranged in accordance with rolling direction of the test material. In the area there are also characteristic striations (Fig. 6). The final overload fracture surface is characterised with a combination of transcrystalline ductile fracture with dimple morphology and transcrystalline quasicleavage fracture (Fig. 8). The area shows very clear combination of the fracture structure with the microstructure of the material (Fig. 7). Pearlite clearly arranged in lines is, after the rolling process, characterised with quasicleavage between which there is ferrite with plastic facture structure and clear dimples morphology.

\section{Conclusions}

The results of the fatigue tests of S355J2 steel are presented in this paper. The results show that S355J2 steel has a clear fatigue limit at the level of $290 \mathrm{MPa}$. Understanding the mechanism of formation fatigue cracks is an important element in safety assurance during the operation of the structure. To ensure safety of the material there was made a fractographic analysis.The fractographic analysis proved that the initiation of fatigue cracks was present on the surface of the test specimens, which was also influenced by their loading. This results from the fact that, while loading, bending in rotation is most intense on the surface of the tested specimen and when the distance from the surface to the specimen's centre increases, its value decreases. The characteristics of the ductile fracture of the fatigue area are closely related to the structure of the material. The results of the fractographic tests proved absence of factors that could have an impact on the decreased strength of the materials and the existing inclusions were not a direct cause of the initiated fatigue crack.

\section{Acknowledgements}

The work was prepared by a grant holder of the program "DoktoRIS - Scholarship program for innovative Silesia" co-financed by the European Union under the European Social Fund.

\section{References}

[1] BoKŮvKa O., Nicoletto G., Kunz L., PalČEK P., ChAlUPOVÁ M. 2002. Low\&High Frequency Fatigue Testing, EDIS University of Žilina.

[2] GAJEWSKI M., 1995. Wady materiałowe oraz błędy w technologii wytwarzania jako przyczyny uszkodzeń części maszyn. Zeszyty Naukowe Politechniki Świętokrzyskiej w Kielcach, Mechanika 55.

[3] Miková K., NovÝ F., TRŠKO L., BOKU゚VKA O. 2012: Únavová životnost' mikrolegovaných oceli pre potrubia určené na transport zemného plynu. In: , SEMDOK 2012. 17th International of PhD. Students' Seminar. Zilina - Terchova, Slovakia 2012.

[4] Ulewicz R., Mazur M., Novy F., Szataniak P. 2012. Fatigue Properties of Selected Grades of Steel Used for Main Components of Semitrailers and Agricultural Machines. W:Advanced Manufacturing and Repair Technologies in Vehicle Industry. 29th International Colloquium. 21-23 May, 2012, Zilina - Terchova, Slovakia.

[5] VĚCHET S., KoHOUT J., BOKŮVKA O. 2001. Únavové vlastnosti tvárné liatiny, EDIS Žilinská Univerzita.

[6] WyrzyKoWsKi J.W., PlesZAKOW E., SIENIAWSKi J. 1999. Odkształcanie i pękanie metali. Wydawnictwo Naukowo-Techniczne.

[7] ZEMANDL M. 2006. Fraktografie únavových lomů a jeji praktické využití při analýze přičin porušeni strojnich součástí. In Letná škola únavy materiálov '2006. EDIS ŽU Žilina. pp. 114-123 